\title{
Immunologic Evaluation in Infective Endocarditis
}

\author{
W ilma C. N eves Forte, A line C. Mario, A dilson da Costa, Luciana S. Henriques, Carla L. Gonzales, \\ Roberto A. Franken
}

São Paulo, SP - Brazil

Objective - To analyze the immune response in peripheral blood of patients with infective endocarditis.

Methods - We studied 10 patients with infective endocarditis, age range from 20 to 50 years-old, males and females, and 20 healthy subjects in the same age range. The diagnosis of the disease was based on the clinical picture, echocardiogram, and hemoculture based upon samples drawn and tested before the treatment started. The were no history of atopy or malnutrition, no autoimmune disease, and they were not using any immunosuppressant or antibiotic medication.

Results - The patients with endocarditis had significantly higher T and B lymphocyte, CD4+ and CD8+ cell counts, IgM and IgG serum levels, and C4 component of the complement than the control group; no significant difference concerning serum IgA and neutrophil oxidative metabolism; a significant decrease in C3, chemotaxis, and monocyte phagocytosis; cryoglobulins were detected in $66.6 \%$ of patients and they were formed by $\operatorname{Ig} G, \operatorname{IgM}, \operatorname{IgA}$, $C 3$, and $C 4$.

Conclusion-The patients with infective endocarditis were immunocompetent in most sectors of immune response and, at a certain moment, an autoimmune component maybe present.

Keywords: cryoglobulin, endocarditis, immune response, autoimmunity

Faculdade de Ciências Médicas da Santa Casa de Misericórdia de São Paulo Mailing address: Roberto Franken - Rua Franco da Rocha, 163/52 - 05015-040 São Paulo, SP, Brazil
Endocarditis starts with the formation of a sterile vegetation composed by fibrin and platelets due to an endocardial lesion. This process is called non-bacterial thrombotic endocarditis ${ }^{1-3}$. In that site, a favorable environment exists for the adherence of microorganisms that are involved by new layers of fibrin and platelets. This picture is called infective endocarditis and usually develops in places where blood goes from a high-pressure source through an orifice to a low-pressure site, because the effects of blood pressure and turbulence are favorable for the deposition of bacteria from the fast stream. It is therefore predominantly located on the left side of the heart, where the mitral and aortic valves are the valves most affected.

All this makes it clear that, for endocarditis to develop, several pathogenetic mechanisms - hemodynamic, immunologic, and microbiologic-are required ${ }^{2}$.

A variety of microbial agents cause infective endocarditis $^{2}$, but the most outstanding are bacteria, first found to be present by Virchow in 1869 and by Winge and Heiberg in 1872. Among these microorganisms, the most important are the following: Streptococcus viridans ${ }^{4-6}$, Streptococcus bovis ${ }^{4}$, Streptococcus agalactiae ${ }^{4}$, Streptococcus gordonii ${ }^{7}$, Haemophilus sp ${ }^{4}$, Actinobacillus actinomycetemcomitans $^{4,8}$, Cardiobacterium hominis, Eikenella sp, and Kingella Kingae ${ }^{4}$. Staphylococcus aureus and Enterococcus faecalis also belong to this list, mainly when associated with community infection and absence of an alternative focus of infection ${ }^{4}$. Less frequently, other microorganisms such as Staphylococcus epidermidis ${ }^{4}$, Coxiella burnetii $^{4,9-11}$, Pseudomonas aeruginosa ${ }^{12}$, and others may also cause endocarditis,

Cicatrization of this process starts even without treatment, but it only becomes complete after antibiotic therapy, when vegetations decrease and become endothelial. The healed valve becomes fibrous and calcified, remaining susceptible to infection for life.

Recent studies suggest that fibronectin, a glucoprotein found in the extracellular matrix of the endothelium, plays an important role in the formation of the sterile thrombus and its colonization. Fibronectin becomes exposed to the blood stream when a lesion of the endothelial li- 
ning occurs, and it is produced in great quantities during the repair of such lesions ${ }^{1}$, being capable of activating the complement system. Certain microorganisms were shown to be able to bind to fibronectin by specific receptors ${ }^{14}$. The number of fibronectin receptors is directly correlated with the virulence of the microorganism ${ }^{15}$. Staphylococcus aureus strains isolated from patients with infective endocarditis were shown to have a great number of such receptors ${ }^{15}$. A great number of links between fibronectin and this bacterium $(56.2 \%)$ were also found ${ }^{16}$.

Certain authors admit that, at a certain point of in the disease, the clinical picture can be maintained by immune processes, regardless of the presence of the microorganism ${ }^{17}$. In this regard, other authors found immune complexes to be present in $97 \%$ of the studied cases and a rheumatic factor in $50 \%$ of cases, depending on their etiology ${ }^{18}$.

Some papers ${ }^{5,17,19-23}$ suggest that extracardiac problems, such as articular, renal, vascular, and skin problems, may be the result of the deposit of circulating immune complexes in the different affected organs. A major proof of the participation of the immune system in infective endocarditis is the renal aggression that coexists with the disease ${ }^{18}$.

Based on the above, what could be the reason for some patients developing only pictures of tonsillitis, whereas others - exposed to the same microorganisms - develop pictures of bacterial endocarditis? Could some a transient immunodeficiency lead to the development of endocarditis? It is known that endocarditis is the result of certain factors predisposing the endothelium to infections (several cardiac lesions) and of situations leading to transient bacteremia.

We decided to perform the present study starting from the existing studies on an immune component in infective endocarditis and from the lack of studies encompassing all sectors of immune response in patients with active infective endocarditis, in addition to the importance of this disease.

\section{Methods}

Peripheral blood drawn from 11 patients with infective endocarditis was analyzed. The disease was diagnosed based on the clinical picture (unspecific signs and symptoms of insidious onset suggesting a picture of infection), on an echocardiogram to view vegetations, and on blood culture for the detection of bacteria (Duke's criteria). Patients ranged between 20 and 50 years of age, were males and females, had no atopy or malnourishment, autoimmune disease or any history of autoimmunity, and other infective diseases, were not using immunosuppressive drugs or antibiotics upon sample collection, which was done immediately before the beginning of treatment (group II). The data found were compared with that from the control group (group I), made up of 20 healthy subjects aged 20 to 50 years. Material collection was performed upon hospital admittance of the patients at the Lung and Heart Unit (Unidade de Pulmão e Coração) - UPCOR - of Hospital Central da Santa Casa de São Paulo, at the same time as samples for other tests were collected, whereby patients gave their consent for the use of part of these tests for research purposes.

Materials were analyzed at the Immunology Laboratory of Faculdade de Ciências Médicas da Santa Casa de São Paulo. The following methods were used: 1 ) thymus-dependent lymphocyte (T lymphocytes) count by immuno-fluorescence microscopy using anti-CD3 monoclonal antibodies, after separation of $3 \times 10^{6}$ lymphocytes $/ \mathrm{mL}$ by means of the Ficoll-Hypaque gradient, the absolute values being obtained from leukograms; 2) bursa-equivalent lymphocyte (B lymphocytes) count by immunofluorescence microscopy using anti-CD4 monoclonal antibodies, after separation of $2 \times 10^{6}$ lymphocytes $/ \mathrm{mL}$ by means of the Ficoll-Hypaque gradient; 3) T lymphocyte subpopulation count by immunofluorescence microscopy using anti-CD4 and anti-CD8 monoclonal antibodies, after separation of $10^{6}$ lymphocytes/ vial by means of the Ficoll-Hypaque gradient, with anti-CD4 and anti-CD 8 being used in $1 / 5$ and $1 / 10$ dilutions, respectively; 4) quantitative dosage of the IgG, IgM, IgA serum immunoglobulins, and of the $\mathrm{C} 3$ and $\mathrm{C} 4$ complement components by simple radial diffusion, and calculation of the concentrations according to the hallus diameter curve, read after 48 and 72 hours; 5) spontaneous and stimulated nitroblue tetrazolium test using $100 \mathrm{~mL}$ heparinized blood, $50 \mathrm{~mL}$ of $0.1 \%$ buffered nitro-blue tetrazolium solution, and $50 \mathrm{~mL}$ bacterial lipopolysaccharide for stimulation. The nitro-blue tetrazolium test makes a direct evaluation of the electron liberation in the transformation of NADPH+ into NADP, these electrons being captured by flavoproteins of the cytoplasmic membrane, transported by the b558 cytochrome and used during the step of digestion by oxidative metabolism; 6) evaluation of monocyte chemotaxis activity: after Ficoll-Hypaque gradient separation of cells, Boyden chambers were used. Three experiments were performed: control; monocytes incubated with bacterial liposaccharide and a pool of normal human serum (homologous serum), and monocytes incubated with bacterial liposaccharide and serum from the patient him or herself (autologous serum). The results were evaluated by migration distance measured in microns. Phagocytosis by monocytes was analyzed, after cell separation, by three analog experiments using Leighton flasks: monocytes (controls), monocytes incubated with Zymosan and homologous serum, and monocytes incubated with Zymosan and autologous serum. The first assay was made to verify whether the cells were alive and the method adequate; homologous serum and autologus sera (AS) supply the necessary complement for phagocytosis: should the results obtained with homologous serum and with AS be different from each other, then the alteration would not necessarily have occurred in the mononuclear phagocyte; 7) detection and identification of cryoprecipitates, allowing a waiting time of 10 days at $4^{\circ} \mathrm{C}$ for the formation of the cryoprecipitate from serum; whenever a cryoprecipitate was formed, it was separated by refrigerated centrifugation at $-10^{\circ} \mathrm{C}$, washed 10 times in saline solution, followed by $\mathrm{IgG}, \operatorname{IgM}, \operatorname{Ig} \mathrm{A}, \mathrm{C} 3$, and $\mathrm{C} 4$ identification by means of simple 
radial immunodiffusion plates, where the diameter of the halo was measured after 48 and 72 hours; parallel heating tests of the cryoprecipitate were made, to exclude fibrinogen.

The monoclonal antibody methodology with radial immunodiffusion dosage has been widely employed. The antibodies used were from Dako Corporation, and the dilutions were 1:10 for CD4, CD8, CD3, CD19, and 1:20 for the conjugate. The nitro-blue tetrazolium test is useful for the evaluation of the oxidative metabolism of polymorphonuclear neutrophils because, if the phagocytosis digestion step of these cells is functionally viable, a liberation of electrons occurs, which are captured by the yellow stain nitroblue tetrazolium, that is then reduced causing formazan, which forms a deposit of blue grains in the cell cytoplasm. The tests on chemotaxis and phagocytosis by mononuclear phagocytes show the directed migration and the ingestion step of these cells, evaluating their functionality, for chemotaxis and phagocytosis depend on the integrity of the monocyte receptors for $\mathrm{C} 3 \mathrm{a}-\mathrm{C} 5 \mathrm{a}$ and $\mathrm{C} 3 \mathrm{~b}-\mathrm{C} 5 \mathrm{~b}$, respectively.

The statistical method used was Student's $t$ test, with values $\leq 0.05$ being considered significant.

\section{Results}

The results are shown in table I (control group) and table II (group of patients with infective endocarditis).

Table I shows a significant increase in T and B lymphocytes, CD4 and CD8 cells, serum IgM and IgG, and the $\mathrm{C} 4$ complement component, a significant decrease in the $\mathrm{C} 3$ complement component without any significant IgA alteration in the patients with endocarditis. Table II shows a significant decrease in the monocyte phagocytosis and chemotaxis values in the endocarditis cases. No significant differences were found between the values of the nitro-blue tetrazolium test.

In addition to that, in eight of the eleven patients with infective endocarditis, the presence of cryoprecipitates was observed, all of them constituted by $\operatorname{IgM}$, IgG, IgA, C3, and C4.

\begin{tabular}{|c|c|c|c|}
\hline \multicolumn{4}{|c|}{$\begin{array}{l}\text { Table I - Results in absolute numbers of B and T lymphocytes, } \\
\text { positive CD4 and CD8 cells, serum levels of immunoglobulins, } \\
\text { and } \mathrm{C} 3 \text { and } \mathrm{C} 4 \text { complement components in patients with infective } \\
\text { endocarditis and in normal subjects }\end{array}$} \\
\hline & Mean & Standard deviation & \\
\hline Group & Endocarditis & Controls & $\begin{array}{c}\text { Significance } \\
\mathrm{P} \leq 0.05\end{array}$ \\
\hline T Lymphocytes & $2914 \pm 1562$ & $1601 \pm 568$ & S \\
\hline B Lymphocytes & $647 \pm 282$ & $343 \pm 147$ & S \\
\hline CD4 + cells & $2317 \pm 791$ & $1213 \pm 467$ & S \\
\hline $\mathrm{CD} 8+$ cells & $1426 \pm 1589$ & $533 \pm 175$ & S \\
\hline $\operatorname{IgM}(\mathrm{mg} / \mathrm{dl})$ & $243 \pm 101$ & $239 \pm 116$ & S \\
\hline $\operatorname{IgG}(\mathrm{mg} / \mathrm{dl})$ & $1971 \pm 307$ & $1496 \pm 507$ & $S$ \\
\hline IgA (mg/dl) & $353 \pm 141$ & $398 \pm 156$ & NS \\
\hline C3 (mg/dl) & $86 \pm 87$ & $156 \pm 58$ & $S$ \\
\hline $\mathrm{C} 4(\mathrm{mg} / \mathrm{dl})$ & $42 \pm 15$ & $29 \pm 29$ & S \\
\hline
\end{tabular}

\begin{tabular}{|c|c|c|c|}
\hline \multicolumn{4}{|c|}{$\begin{array}{l}\text { Table II - Chemotaxis results (distances in micra), monocyte } \\
\text { phagocytosis (percentage of monocytes, out of a fixed number of } \\
\text { 200, which phagocyte } 3 \text { or more Zymosan particles) and nitro-blue } \\
\text { tetrazolium (NBT) test for neutrophils in patients with infective } \\
\text { endocarditis (group II) and normal subjects (group I) }\end{array}$} \\
\hline Group & Endocarditis & Controls & $\begin{array}{l}\text { Significance } \\
\quad \mathrm{P} \leq 0.05\end{array}$ \\
\hline $\begin{array}{l}\text { Monocyte chemotaxis- } \\
\text { Control }\end{array}$ & $20 \pm 13$ & $27 \pm 5$ & NS \\
\hline $\begin{array}{l}\text { Monocyte chemotaxis- } \\
\text { homologous serum }\end{array}$ & $45 \pm 29$ & $65 \pm 7$ & S \\
\hline $\begin{array}{l}\text { Monocyte chemotaxis- } \\
\text { autologous serum }\end{array}$ & $47 \pm 30$ & $68 \pm 7$ & S \\
\hline $\begin{array}{l}\text { Monocyte phagocytosis- } \\
\text { Control }\end{array}$ & $13 \pm 7$ & $18 \pm 5$ & NS \\
\hline $\begin{array}{l}\text { Monocyte phagocytosis- } \\
\text { homologous serum }\end{array}$ & $52 \pm 20$ & $63 \pm 7$ & S \\
\hline $\begin{array}{l}\text { Monocyte phagocytosis- } \\
\text { autologous serum }\end{array}$ & $56 \pm 20$ & $66 \pm 6$ & $S$ \\
\hline Spontaneous NBT & $9 \pm 4$ & $11 \pm 3$ & NS \\
\hline Stimulated NBT & $19 \pm 9$ & $20 \pm 4$ & NS \\
\hline significant; NS- nons & icant. & & \\
\hline
\end{tabular}

\section{Discussion}

In an attempt to have infective endocarditis as the only variable, a selection was made immediately before onset of treatment of patients with this disease, but without any atopy, malnutrition, or other systemic diseases and without any autoimmunity antecedents.

Experiments were performed in duplicate and wellestablished techniques were used ${ }^{24,25}$.

The significantly increased results found for bursaequivalent lymphocytes (CD19 positive cells), thymus-dependent lymphocytes (CD3 positive cells) and subpopulations of auxiliary (CD4 positive) and cytotoxic (CD8 positive) cells, as well as the increase of serum levels of $\mathrm{IgM}$, IgG, and the $\mathrm{C} 4$ complement component in the endocarditis patients are consistent with values usually observed in the presence of infections.

Papers ${ }^{26,27}$ published in the literature show high IgM, $\mathrm{IgG}$, and IgA titles in patients with infective endocarditis. No studies were found with an evaluation of T and B lymphocytes and positive CD4 and CD8 cells in active endocarditis, except for a rare and atypical form of endocarditis caused by Coxiella burnetii that develops with rare vegetations and a negative blood culture ${ }^{11}$. In this case, in addition to cryoglobulinemia and polyclonal gammopathy ${ }^{11}$, a decrease of $\mathrm{B}$ (CD19 positive) and T (CD3 positive) lymphocytes was shown, the decrease being greater in the CD4 positive cells than in the CD8 positive cells ${ }^{28}$, suggesting that this type of endocarditis might be associated with a suppression of lymphocyte response to specific antigens ${ }^{10}$. A significant increase in of alpha-TNF and beta-IL-1, proinflammatory cytokines produced by activated monocytes during the inflammation process, besides an increase of IgG and $\operatorname{IgA}$ and of immune complexes were also found in this type of endocarditis ${ }^{10}$. 
Cryoglobulinemia was also observed in another study on subacute bacterial endocarditis ${ }^{29}$.

The presence of a cryoprecipitate formed by IgG, IgM, IgA, C3, and C4-observed in most of the patients in this study suggests that the disease may have an autoimmune character. The data found on the decrease of the $\mathrm{C} 3$ complement component and the monocyte activity contribute further to this hypothesis. For instance, complement is frequently consumed in active autoimmune diseases. Likewise, mononuclear phagocytes need to be perfectly functional to be able to break down circulating immune complexes. Factors involved in the adhesion of monocytes or bacteria, or both to the surface of vegetations can affect phagocytosis of bacteria by mononuclear phagocytes ${ }^{30}$. It was observed that fibronectin, a component of the extracellular matrix, may be involved in the adhesion of the bacterium to the surface of the endocardial vegetations by causing a strong adhesion and thus leading to a decreased monocyte phagocytosis ${ }^{30}$.

The mononuclear phagocytes of the studied patients with endocarditis showed decreased chemotaxis and phagocytosis, which might contribute to a smaller breakdown of circulating immune complexes and the consequent presence of cryoglobulins. Reduction of monocyte chemotaxis and phagocytosis does not usually occur in infections.

When phagocytosis is evaluated in the presence of homologous serum, the $\mathrm{C} 3$ component is supplied, and it will link to the $\mathrm{C} 3$ receptor present in monocytes, allowing phagocytosis to occur. If this is decreased, it implies that an intrinsic cellular problem exists in the monocyte, a fact that is confirmed by supplying autologous serum and there being no difference between phagocytosis with homologous and with autologous serum (both equally decreased).

Earlier studies found a decrease in the $\mathrm{C} 3$ and $\mathrm{C} 4$ complement components and the presence of circulating immune complexes in patients with endocarditis ${ }^{5,17-21,31}$. Some authors describe an increase in circulating immune complexes as the disease progresses and a decrease with treatment ${ }^{5}$. Other investigators correlate the immune complex findings with the endocardial infection rather than with the endocardial defect ${ }^{17,20}$. Some papers show a genetic predisposition in patients with infective endocarditis, the most frequent haplotype being HLA-B35 $5^{32}$, suggesting a greater susceptibility of certain individuals to the disease.

Our results, showing a significant increase of $\mathrm{T}$ and $\mathrm{B}$ lymphocytes, CD4+ and CD8+ cells, IgM, IgG, and C4 complement component, are consistent with those observed in immunocompetent individuals during infections. On the other hand, the significant decrease observed with regard to the $\mathrm{C} 3$ complement component, chemotaxis, and phagocytosis by monocytes, and the presence of cryoprecipitates in the serum of patients with endocarditis lead to the conclusion that the disease has also an autoimmune component.

It is possible that infective endocarditis is determined by an aggressor microorganism associated with an autoimmune component, as suggested by the presence of cryoglobulin in the serum of these patients.

\section{References}

1. João SR, Afonso MRB, Júnior LM, Júnior BNA, França HH. Aspectos patogênicos e imunitários da endocardite infecciosa. Arq Bras Cardiol 1990; 54: 69-72.

2. Anguita M, Torres F, Castillo JC, Valles F. Etiopathogenesis of infective endocarditis: predisposing heart diseases and casual microorganisms. Rev Esp Cardiol 1998; 2: 11-5.

3. Assef MAS, Wüstbuf AR, Cleiter LY, et al. Análise da febre em 58 casos de endocardite infecciosa. Arq Bras Cardiol 1992; 58: 107-12.

4. Durack DT, Lukes AS, Bright DK. New criteria for diagnosis of infective endocarditis: utilization of specific echocardiographic findings. Am J Med 1994; 96: 200-9.

5. Deck CR, Guarda ES, Bianchi CC, et al. Complejos immunes circulantes en endocarditis infecciosa. Rev Mèd Chile 1988; 116: 1101-4.

6. Jiang Y, Magli L, Russo M. Bacterium-dependent induction of cytokines in mononuclear cells and their pathologic consequences in vivo. Infec Immun 1999; 67: 2125-30.

7. Sommer P, GleyzalC, Guerret S, Etienne J, Grimaud J. Induction of a putative laminin-binding protein of Streptococcus gordonii in human infective endocarditis. Infective Immun 1992; 60: 360-5.

8. Wilson ME, Genco RJ. The role of antibody, complement and neutrophils in host defense against Actinobacillus actinomycetemcomitans. Immunol Invest 1989; 18: 187-209.

9. Atzpodien E, Baumgartner W, Artelt A, Thiele D. Valvular endocarditis occurs as a part of a disseminated Coxiella burnetii infection in immunocompromised $\mathrm{BALB} / \mathrm{cJ}(\mathrm{H}-2 \mathrm{~d})$ mice infected with the nine mile isolate of C. burnetii. J Infect Dis 1994; 170: 223-6.

10. Capo C, Zugun F, Stein A, et al. Upregulation of tumor necrosis factor alpha and interleukin-1 beta in Q fever endocarditis. Infec Immun 1996; 64: 1638-42.

11. Glasseim M, Agger WA, Vanscoy RE, Howe GB. Chronic sternal wound infection and endocarditis with Coxiella burnetii. Clin Infect Dis 1999; 28: 1249-51.
12. Oshima T, Nakaya T, Saito K, Maeda H, Nagano T. Child neglect followed by marked thymic involution and fatal systemic Pseudomonas infection. Int J Legal Med 1991; 104: 167-71.

13. Assef MAS, Gandra SMA, Franken RA. Endocardite infecciosa. Estudo de 83 casos no Hospital da Santa Casa de São Paulo. Arq Bras Cardiol 1991; 56: 195-9.

14. Mosher DF, Proctor RA. Binding and factor XIII a-mediated cross-linking of a 27-kilodalton fragment of fibronectin to Staphylococcus aureus. Science 1980; 209: 927-9.

15. Proctor RA, Cristman G, Mosher DF. Fibronectin induced agglutination of Staphylococcus aureus correlates with invasiveness. J Lab Clin Med 1984; 104: 455-69.

16. ScheldWM, Strunk RW, Balian G, Calderone RA. Microbial adhesion to fibronectin in vitro correlates of endocarditis in rabbits. Proc Soc Exp Biol 1985; 180: 474-82.

17. Kaufmann RH, Thompson J, Valentijn RM, Daha MR, Vanes LA. The clinical implications and the pathogenetic significance of circulating immune complexes in infective endocarditis. Am J Med 1981; 71: 17-25.

18. Sabbagh AZ, Cohen RV, Tsunematsu EK, Bicego VC, Saber S, Júnior EBA. Endocardite infecciosa-a utilidade do enfoque imunológico. An Paul Med Cir 1985; 112: 23-9.

19. Roblot P, Barrier J, Roblot F, Muller A, Marechaud R. Is the immunologic evaluation in endocarditis of value? Rev Med Interne 1993; 14: 1031.

20. Bayer AS, Theofilopovios NA, Eisenberg R, Dixon FJ, Guze LB. Circulating immune complexes in infective endocarditis. N Engl J Med 1976; 295: 1500-5.

21. Cabane J, Godeau H, Acar M, Bach JF. Fate of circulating immune complexes in infective endocarditis. Am J Med 1979; 66: 277-81.

22. Gao GW, Lin YF, Diang LK, Lu KC, Shied SD. Infective endocarditis complicated with rapidly progressive glomerulonephritis: a case report. Chung Hua I Hsueh Tsa Chih 1996; 57: 438-42. 
23. Harris PS, Cobbs CG. Cardiac cerebral and vascular complications of infective endocarditis. Cardiol Clin 1996; 14: 437-50.

24. Forte WCN, Gonzales CCL, Carignam S, Mimica I. Avaliação de neutrófilos na desnutrição moderada. Rev Ass Med Bras 1999; 45: 147-51.

25. Forte WCN, Campos JVM, Leão RC. Non specific immunological response in moderate malnutrition. Allerg Immunopathol 1984; 12: 489-95.

26. Planes AM, Bernejo B, Tornos MP, Fernandez F, Arcalis L. Serologic study in patients with streptococcal infective endocarditis. Med Clin 1996; 107(18):693-7.

27. Agarwal R, Bahl VK, Malaviya NA, Krishnan S, Chopra P. Immunologic parameters in infective endocarditis: a prospective study. Indian Heart J 1991; 43: 179-83.

28. SabatierF, Dignat-George F, Mege JL, Brunet C, Raoult D, Sampol J. CD4+T-cell lymphopenia in Q fever endocarditis. Clin Diagn Lab Immunol 1997; 4: 89-92.
29. Agarwal A, Clements J, Sedmak DD, et al. Subacute bacterial endocarditis masquerading as type III essential mixed cryoglobulinemia. J Am Soc Nephrol 1997; 8: 1971-6.

30. Bancisi MJ, Veltrop MH, Bertina RM, Thompson J. Role of phagocytosis in activation of the coagulation system in Streptococcus sanguis endocarditis. Infect immun 1996; 64: 5166-70.

31. Barrier J, Roblot P, Ramassamy A, Becq-Geraudon B. Immunologic sutdies in the differential diagnosis of infectious endocarditis and septicemia without endocardiac lesion. Rev Med Interne 1996; 17: 21-4.

32. Shevchenko IUL, Danilchenko VV, Zhilourt EB, Serebrianaia NB, Khubulava GG, Katkova IV. The immunogenetic status of patients with infectious endocarditis. Vestn Khir Im II Grek 1995; 154: 36-58. 